\title{
Dynamic Interfaces between Cells and Surfaces: Electroactive Substrates that Sequentially Release and Attach Cells
}

\author{
Woon-Seok Yeo, Muhammad N. Yousaf, and Milan Mrksich*
}

The University of Chicago, Department of Chemistry, Institute for Biophysical

Dynamics, 5735 S. Ellis Ave., Chicago, Illinois 60637

\section{Supporting Information}

OH
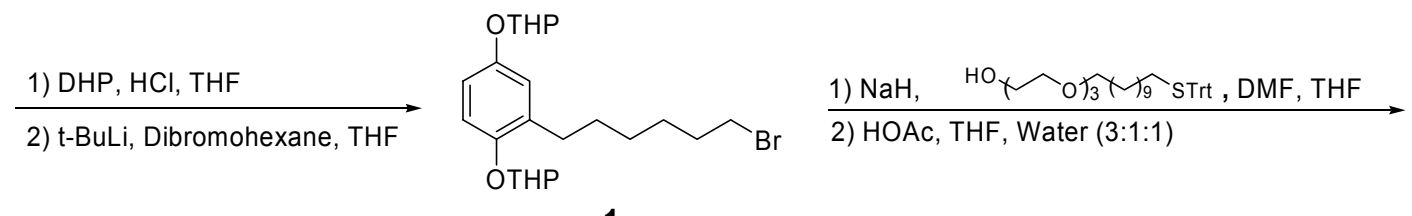

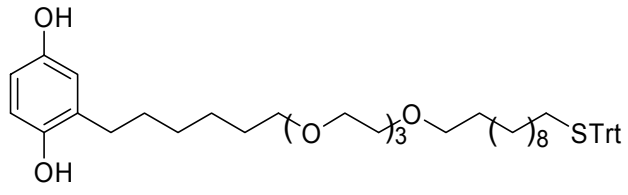

2
$\underset{\mathrm{THF}}{\stackrel{\mathrm{DBU}, 3}{\longrightarrow}}$

THF

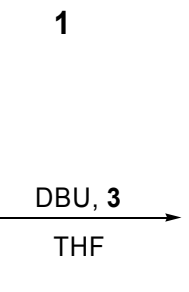

$\mathrm{H}_{2} \mathrm{~N}_{+}^{+} \mathrm{NH}_{2}$

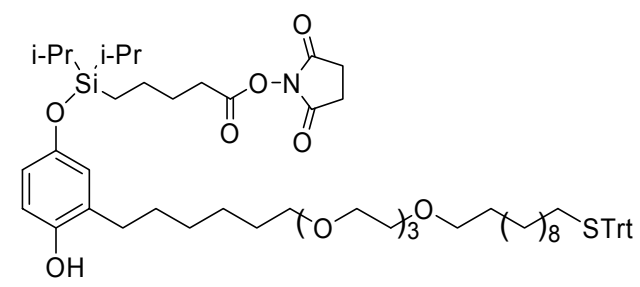

4<smiles>C=CCCC(=O)O</smiles>

Scheme Synthesis of E*-RGD. For details, see below. 


\section{2-(2-(6-bromohexyl)-4-(tetrahydro-2H-pyran-2-yloxy)phenoxy)-tetrahydro-2H-}

pyran (1). To a solution of hydroquinone $(5 \mathrm{~g}, 45.4 \mathrm{mmol})$ in THF $(20 \mathrm{~mL})$, was added dihydropyran $(17 \mathrm{~mL}, 180 \mathrm{mmol})$ and $2 \mathrm{~mL}$ of concentrated $\mathrm{HCl}$. The reaction mixture was stirred for $8 \mathrm{hrs}$ and then diluted with $50 \mathrm{~mL}$ of EtOAc. The organic layer was washed with saturated $\mathrm{NaHCO}_{3}$, water, brine, dried over $\mathrm{MgSO}_{4}$ and concentrated to a white solid. Silica gel chromatography with 5:1 hexane/ethyl acetate afforded $2.5 \mathrm{~g}$ (20 $\%$ of 2-(4-(tetrahydro-2H-pyran-2-yloxy)phenoxy)-tetrahydro-2H-pyran as a white solid: ${ }^{1} \mathrm{H}$ NMR (500 MHz, $\left.\mathrm{CDCl}_{3}\right) \delta 6.95(\mathrm{~s}, 4 \mathrm{H}), 5.28(\mathrm{t}, 2 \mathrm{H}, J=4.0 \mathrm{~Hz}), 3.88-3.94(\mathrm{~m}$, 2H), 3.55-3.58 (m, 2H), $1.96(\mathrm{~m}, 2 \mathrm{H}), 1.82(\mathrm{~m}, 4 \mathrm{H}), 1.61(\mathrm{~m}, 6 \mathrm{H})$.

To a solution of 2-(4-(tetrahydro-2H-pyran-2-yloxy)phenoxy)-tetrahydro-2H-pyran (503 $\mathrm{mg}, 1.8 \mathrm{mmol})$ in THF, was added $t$-butyllithium (1.6 $\mathrm{mL}$ of $1.7 \mathrm{M}$ solution in pentane) dropwise over $5 \mathrm{~min}$ at $0{ }^{\circ} \mathrm{C}$. The reaction mixture was stirred for $1 \mathrm{hr}$ at room temperature, followed by the addition of 1,6-dibromohexane $(1.1 \mathrm{~mL})$, and then stirred for $12 \mathrm{hrs}$. The reaction mixture was diluted with $30 \mathrm{~mL}$ of EtOAc, washed with saturated $\mathrm{NH}_{4} \mathrm{Cl}$, then brine, and dried over $\mathrm{MgSO}_{4}$. The organic layer was concentrated and purified by column chromatography with 8:1 hexane/ethyl acetate to give $738 \mathrm{mg}$ (92 \%) of product 1 as a colorless oil: ${ }^{1} \mathrm{H}$ NMR $\left(500 \mathrm{MHz}, \mathrm{CDCl}_{3}\right) \delta 7.02(\mathrm{~m}, 1 \mathrm{H}), 6.84(\mathrm{~m}$, $2 \mathrm{H}), 5.28(\mathrm{t}, 2 \mathrm{H}, J=4.0 \mathrm{~Hz}), 3.88-3.94(\mathrm{~m}, 2 \mathrm{H}), 3.55-3.58(\mathrm{~m}, 2 \mathrm{H}), 3.38(\mathrm{t}, 2 \mathrm{H}, J=7.8$ $\mathrm{Hz}), 2.58(\mathrm{t}, 2 \mathrm{H}, J=7.5 \mathrm{~Hz}), 1.62-2.02(\mathrm{~m}, 20 \mathrm{H})$.

\section{2-(6-(2-(2-(2-(11-(tritylthio)undecyloxy)ethoxy)ethoxy)ethoxy)hexyl)benzene-1,4-diol}

(2). To a solution of a S-trityl tri(ethylene glycol)-terminated alkanethiol (1.06g, 1.83 mmol) in THF $(10 \mathrm{~mL})$ was added $\mathrm{NaH}(250 \mathrm{mg})$ portionwise at $0{ }^{\circ} \mathrm{C}$. The reaction 
mixture was stirred for $2 \mathrm{hrs}$ at room temperature, followed by the addition of bromide $\mathbf{1}$ (1.02 $\mathrm{mg}, 2.30 \mathrm{mmol}$ ) in $5 \mathrm{~mL}$ of THF, and stirred for $12 \mathrm{hrs}$ at room temperature. The reaction mixture was quenched with water, diluted with $30 \mathrm{~mL}$ of EtOAc, washed with saturated $\mathrm{NH}_{4} \mathrm{Cl}$, then brine, and dried over $\mathrm{MgSO}_{4}$. The organic layer was concentrated and purified by column chromatography with 2:1 hexane/ethyl acetate to give $876 \mathrm{mg}$ (51 $\%)$ of the conjugate as a colorless oil: ${ }^{1} \mathrm{H}$ NMR $\left(500 \mathrm{MHz}, \mathrm{CDCl}_{3}\right) \delta 7.42(\mathrm{~m}, 6 \mathrm{H}), 7.28$ (m, 6H), $7.20(\mathrm{~m}, 3 \mathrm{H}), 7.02(\mathrm{~m}, 1 \mathrm{H}), 6.84(\mathrm{~m}, 2 \mathrm{H}), 5.28(\mathrm{t}, 2 \mathrm{H}, J=4.0 \mathrm{~Hz}), 3.88-3.94(\mathrm{~m}$, $2 \mathrm{H}), 3.42-3.65(\mathrm{~m}, 18 \mathrm{H}), 2.58(\mathrm{t}, 2 \mathrm{H}, J=7.5 \mathrm{~Hz}), 2.12(\mathrm{t}, 2 \mathrm{H}, J=6.8 \mathrm{~Hz}), 1.15-2.02(\mathrm{~m}$, $38 \mathrm{H})$.

The resulting conjugate $(825 \mathrm{mg}, 0.88 \mathrm{mmol})$, was dissolved in $10 \mathrm{~mL}$ of $\mathrm{AcOH}$ : THF : $\mathrm{H}_{2} \mathrm{O}(3: 1: 1)$ solution. The reaction mixture was stirred overnight. Evaporation of solvent gave product 2 as a colorless oil: ${ }^{1} \mathrm{H}$ NMR $\left(500 \mathrm{MHz}, \mathrm{CDCl}_{3}\right) \delta 7.42(\mathrm{~m}, 6 \mathrm{H})$, $7.28(\mathrm{~m}, 6 \mathrm{H}), 7.20(\mathrm{~m}, 3 \mathrm{H}), 7.02(\mathrm{~m}, 1 \mathrm{H}), 6.84(\mathrm{~m}, 2 \mathrm{H}), 3.42-3.65(\mathrm{~m}, 18 \mathrm{H}), 2.53(\mathrm{t}, 2 \mathrm{H}$, $J=7.5 \mathrm{~Hz}), 2.12(\mathrm{t}, 2 \mathrm{H}, J=6.8 \mathrm{~Hz}), 1.15-1.58(\mathrm{~m}, 26 \mathrm{H})$.

5-(chlorodiisopropylsilyl)pentanoic NHS ester (3). To a solution of pentenoic acid $(1.02 \mathrm{~mL}, 10 \mathrm{mmol})$ in methylene chloride $(10 \mathrm{~mL})$, N-hydroxysuccinimide $(1.27 \mathrm{~g}, 11$ mmol) and DCC (2.27 g, $11 \mathrm{mmol})$ were added. The reaction mixture was stirred for 2 hrs and stored at $-20^{\circ} \mathrm{C}$ overnight. The white precipitate was filtered, and the filtrate was concentrated and purified by column chromatography with 1:2 ethyl acetate/hexane to give $1.21 \mathrm{~g}(61 \%)$ of pentenoic NHS ester as a white powder: ${ }^{1} \mathrm{H}$ NMR $\left(\mathrm{CDCl}_{3}\right) \delta 5.85$ (m, 1H), $5.11(\mathrm{~m}, 2 \mathrm{H}), 2.83(\mathrm{~s}, 4 \mathrm{H}), 2.71(\mathrm{t}, 2 \mathrm{H}, \mathrm{J}=7.5 \mathrm{~Hz}), 2.48(\mathrm{~m}, 2 \mathrm{H})$. 
To a solution of pentenoic NHS ester $(150 \mathrm{mg}, 0.76 \mathrm{mmol})$ and $\mathrm{H}_{2} \mathrm{PtCl}_{6}(5 \mathrm{mg})$ in THF, diisopropylchlorosilane $(0.26 \mathrm{~mL}, 1.52 \mathrm{mmol})$ was added dropwise. The reaction mixture was stirred overnight at $60{ }^{\circ} \mathrm{C}$ under $\mathrm{N}_{2}$ atmosphere. Solvent was evaporated and the residue was washed with hexanes. The obtained yellow oil was used without further purification and characterization.

\section{5-((3-(6-(2-(2-(2-(11-(tritylthio)undecyloxy)ethoxy)ethoxy)ethoxy)hexyl)-4-}

hydroxyphenoxy) diisopropylsilyl)pentanoic NHS ester (4). To a solution of 2 (142 $\mathrm{mg}, 0.165 \mathrm{mmol})$ in THF $(10 \mathrm{~mL})$, was added DBU ( $58 \mu \mathrm{L}, 0.33 \mathrm{mmol})$ followed by 3 ( $86 \mathrm{mg}, 0.25 \mathrm{mmol}$ ) at $0{ }^{\circ} \mathrm{C}$. The reaction mixture was stirred $5 \mathrm{hrs}$ and then diluted with EtOAc, washed with saturated $\mathrm{NH}_{4} \mathrm{Cl}$, then brine, and dried over $\mathrm{MgSO}_{4}$. The organic layer was concentrated and purified by column chromatography with 1:1 ethyl acetate/hexane to give $160 \mathrm{mg}(83 \%)$ of 4 as a pale yellow oil: ${ }^{1} \mathrm{H}$ NMR $(500 \mathrm{MHz}$, $\left.\mathrm{CDCl}_{3}\right) \delta 7.42(\mathrm{~m}, 6 \mathrm{H}), 7.28(\mathrm{~m}, 6 \mathrm{H}), 7.20(\mathrm{~m}, 3 \mathrm{H}), 6.53-6.63(\mathrm{~m}, 3 \mathrm{H}), 3.42-3.65(\mathrm{~m}$, $18 \mathrm{H}), 2.82(\mathrm{~s}, 4 \mathrm{H}), 2.55(\mathrm{~m}, 4 \mathrm{H}), 2.12(\mathrm{t}, 2 \mathrm{H}, J=6.8 \mathrm{~Hz}), 0.6-1.58(\mathrm{~m}, 46 \mathrm{H})$.

E*-RGD. To a solution of 4 ( $17 \mathrm{mg}, 0.0145 \mathrm{mmol})$ in DMF ( $5 \mathrm{~mL})$, was added GRGDS peptide $(8 \mathrm{mg}, 0.0125 \mathrm{mmol})$ followed by DIEA $(11 \mu \mathrm{l})$. The reaction mixture was stirred overnight at $50{ }^{\circ} \mathrm{C}$ under $\mathrm{N}_{2}$ atmosphere. Solvent was evaporated and the residue was redissolved in $\mathrm{MeOH}$. Trituration with ether gave the conjugate ( $9 \mathrm{mg}, 40 \%$ ) as a white solid. To a solution of this conjugate in $10 \% \mathrm{TFA} /$ methylene chloride $(\mathrm{v} / \mathrm{v}, 5 \mathrm{~mL})$, was added one drop of triethylsilane as a carbocation scavenger. The reaction mixture was stirred for $2 \mathrm{hrs}$. The solvent was evaporated and the residue was redissolved in 
$\mathrm{MeOH}$. Trituration with ether gave $\mathbf{E}^{*}-\mathbf{R G D}\left(5 \mathrm{mg}, 66 \%\right.$ ) as a white solid: ${ }^{1} \mathrm{H}$ NMR (500 MHz, CD $\left.{ }_{3} \mathrm{OD}\right) \delta 6.49-6.63(\mathrm{~m}, 2 \mathrm{H}), 4.73(\mathrm{t}, 1 \mathrm{H}, J=6.5 \mathrm{~Hz}), 4.39(\mathrm{~m}, 1 \mathrm{H}), 4.34(\mathrm{~m}$, 1H), 3.81-3.91 (m, 6H), 3.43-3.65 (m, 18H), $3.19(\mathrm{~m}, 2 \mathrm{H}), 2.78-2.90(\mathrm{~m}, 2 \mathrm{H}), 2.52(\mathrm{~m}$, 4H), $2.29(\mathrm{~m}, 2 \mathrm{H}), 1.90(\mathrm{~m}, 1 \mathrm{H}), 1.74(\mathrm{~m}, 1 \mathrm{H}), 0.6-1.65(\mathrm{~m}, 48 \mathrm{H})$.

\section{Cyclic Voltammetry.}

To gain additional evidence that the electrochemical oxidation of immobilized diethylisopropylsilyl hydroquinone generates a benzoquinone group, we used cyclic voltammetry to observe the generation of the redox active quinone. A monolayer was prepared as described in Figure S1. The initial voltammetric scan was towards negative potentials and showed no wave for the benzoquinone group. After cycling to positive potentials, the second scan showed a wave for reduction of benzoquinone at $-190 \mathrm{mV}$, which continued to increase in intensity, reaching a maximum current after several cycles. The oxidation wave is diffuse and not apparent in the cyclic voltammograms. Further, the resulting reduction wave decreased when cyclopentadiene was added to the electrolyte, owing to a Diels-Alder reaction with the quinone (data not shown). 


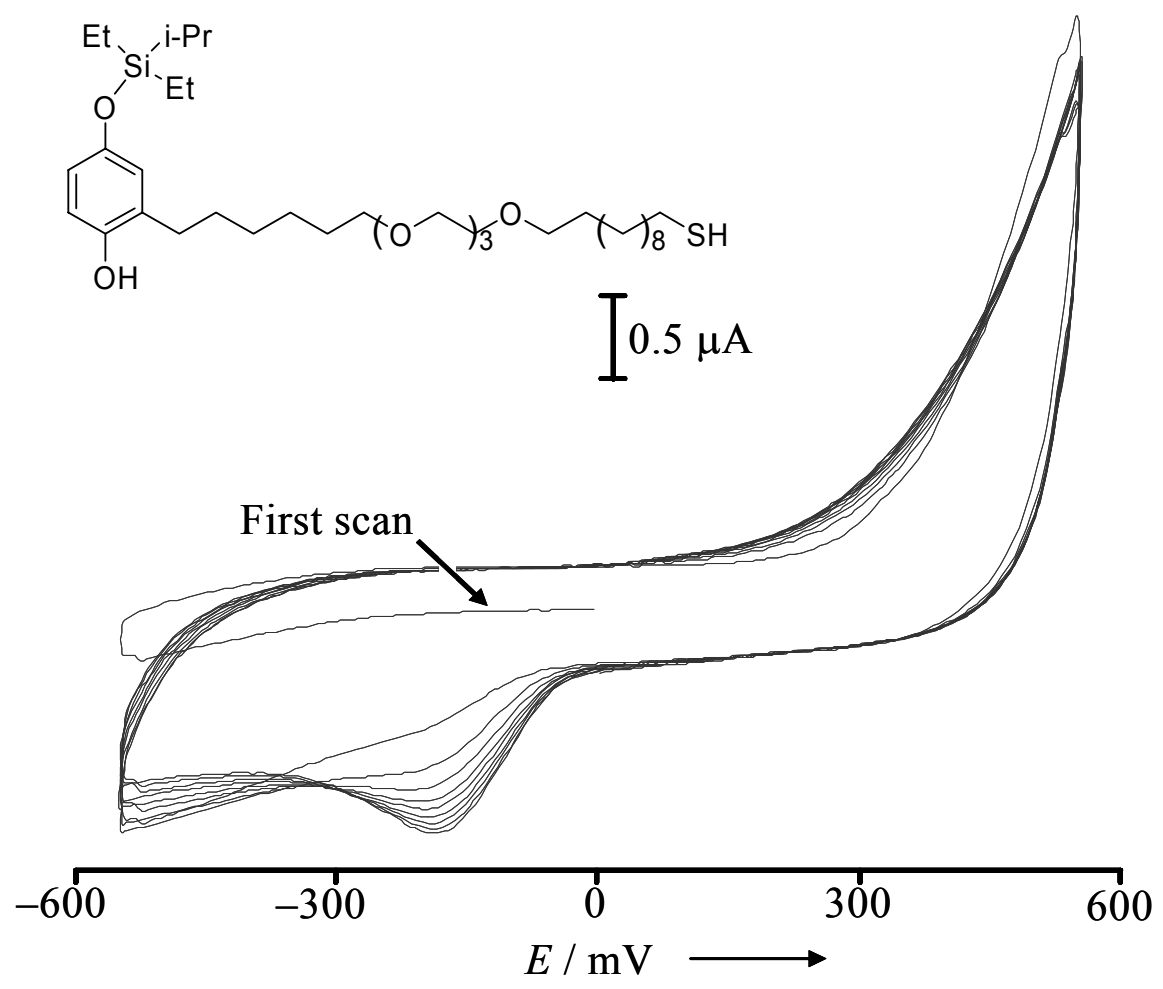

Figure S1 Cyclic voltammograms showing the electrochemical cleavage of trialkylsilyl groups from hydroquinone moiety. SAMs were prepared with a diethylisopropylsilyl hydroquinone-terminated alkanethiol (inset) and a tri(ethylene glycol)-terminated alkanethiol in a ratio of 1:4. Cyclic voltammetry was performed with a Bioanalytical Systems CV-50W potentiostat using PBS as the electrolyte at $\mathrm{pH}$ 7.4, with scanning from $-550 \mathrm{mV}$ to $+550 \mathrm{mV}$ at $100 \mathrm{mV} / \mathrm{s}$. All experiments used a custom-designed electrochemical cell with the monolayer as the working electrode, a Pt wire as the counter electrode, and an $\mathrm{Ag} / \mathrm{AgCl}$ reference electrode.

\section{Cell Migration with Control Peptide.}

To verify that the migration of cells following the activated immobilization of RGD peptides is indeed due to a specific interaction of the peptides and cell-surface integrin receptors, we performed a control experiment using a RGE peptide (which is known to be inactive in binding the integrin receptors). The control experiment was performed according to the procedure described in the paper, with the only difference that RGE-Cp was used in place of RGD-Cp. The optical micrographs in Figure S2 reveal that cells did 
not respond to the immobilization of RGE, and therefore that the migration of cells on substrates that turn on the immobilization of RGD is bio-specific.
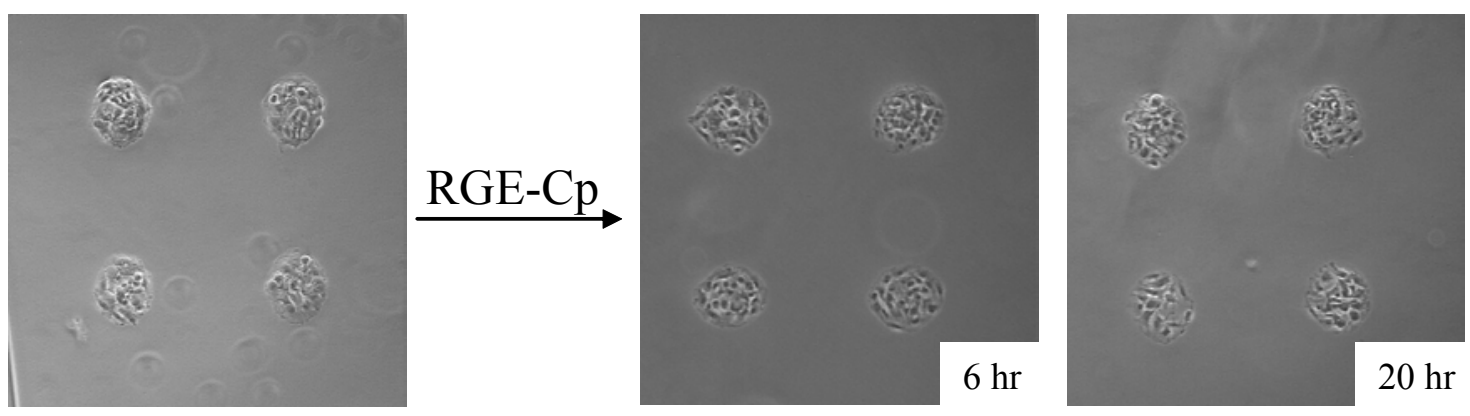

Figure S2 Optical micrographs showing that patterned cells do not migrate on a monolayer to which the RGE peptide was immobilized. 